\title{
BUILDING EMPATHY BY WATCHING APOLOGIES: PERCEPTIONS OF FACILITATORS REGARDING BYSTANDERS AND PERPETRATORS
}

\section{Volks*}

Director: HIVIAIDS, Inclusivity \& Change Unit

e-mail: cal.volks@uct.ac.za

\section{S. Musungu*}

Project Officer: HIVIAIDS, Inclusivity \& Change Unit

e-mail: stella.musungu@uct.ac.za

*University of Cape Town

Cape Town, South Africa

\section{ABSTRACT}

A group of Cape Town Holocaust Centre volunteer educators were shown a video of an apology from a representative of bystanders who had lived in Germany in World War II apologising for not stopping a specific act of violence. The research aimed to investigate how individuals (educators or facilitators in this case) may be likely to be more available for increased reflection and understanding. These are conversations that are overdue in South Africa. We caution against apologies being taught as alternatives to reparations and bringing perpetrators to justice or this being taught as if apologies that are perceived as papering over cracks are what is required. Researchers recommend that these kinds of material be used in academic curricula across a range of subjects in the Humanities.

Keywords: apologies, bystanders, perpetuators, forgiveness, empathic repair, agency

\section{INTRODUCTION}

Using a psychoanalytic conceptualization of the capacity for empathic repair (based on Emmanuel Levina's' ethics of responsibility for the other), Gobodo-Madikizela (2008, 334) has described the potential for empathic healing in the participants who witnessed the event of public apologies during the Truth and Reconciliation Commission in South Africa. Applying this concept to another setting, the researchers set out to explore this concept as a strategy for impeding intergenerational transmission of trauma through teaching history students. A group of Cape Town Holocaust Centre volunteer educators were shown (in a pilot study) a video of an apology from a representative of bystanders who had lived in Germany in World War II, apologising for not stopping a specific act of violence. 
These are conversations that are overdue in South Africa. We caution against apologies being taught as alternatives to reparations and bringing perpetrators to justice or this being taught as if apologies that are perceived as papering over cracks are what is required.

While this research began in 2013, in 2015 and 2016 there is significant discussion about apologies that are meaningful and those that are not. In an article about an apology for wearing 'blackface' at a University event, Msimang $(2014,1)$ writes of the person who committed the racist act and apologised, 'This is part of a long history of white non-apologies for racist behavior. This sort of sorry-ness wears a smile but has a dangerous bite. This kind of sorry-ness is self-serving and so it doesn't learn from the “forgiveness” it seeks. It simply mutates and becomes bolder over time. It is a fake, shallow sorry-ness that is beginning to make me feel nauseous’ (Msimang 2014, 1).

Chigumadzi (2016, 2) writes in the Rand Daily Mail, in her article, We will only accept apologies in white generational wealth and land, about the crucial structural changes that are required by White people to bring about true equality between the races in South Africa since wealth and power is still in the hands of White people. Chigumadzi $(2016,2)$ writes:

On the one hand are young black people who are becoming increasingly 'militant' and 'radical' as they, for example, casually discuss the once taboo topic of land. They are the people who provide the steam for student-led 'Fallist' movements .... White South Africans wring their hands at the state of racial affairs, asking, 'But what exactly do black people want us to do?' Black people have been very clear about what exactly it is they want - they say 'land', 'redistribution of wealth' and yet it falls on deaf ears. Why? Because it is more than just an inconvenient truth, it would fundamentally change the status quo ... the land question is a proxy for the socioeconomic justice and radical redistribution necessary to deconstruct our colonial past and present ... until 'apologies' are tendered in the currency of socioeconomic justice and the redistribution of white generational wealth and land replaces crocodile tears, I would rather not accept its current tender.

This curriculum piece is particularly important because the Germans paid financial reparations to Jewish survivors of Nazi Germany and this is a case study where there was not just an apology, but also reparations.

\section{BACKGROUND LITERATURE}

Using a psychoanalytic conceptualization of the capacity for empathic repair (based on Emmanuel Levinas' ethics of responsibility for the other), Gobodo-Madikizela (2008, 332) writes about the process of forgiveness, which she terms 'empathic healing', in participants who witnessed the event of public apologies during the Truth and Reconciliation Commission (TRC) in South Africa. This has application and relevance for other incidents of trauma and violence. 
The research aimed to investigate how individuals (educators or facilitators in this case) may be likely to be more available for increased reflection and understanding, following efforts to bring about 'empathic healing' by bystanders. If this worked well it may be viable to teach students with this material.

The HIV/AIDS, Inclusivity \& Change Unit (HAICU), based in the Transformation Office and Office of the Vice Chancellor creates platforms for dialogue by facilitating academic literacies (critical thinking), research and workplace competencies (communication), and global citizenship attributes (social responsiveness, appreciation for diversity). In class and out of class gatherings where students can critically engage and reflect on the subject of contexts which give rise to violence and how it intersects with intergenerational trauma. Jewkes, Dunkle, Nduna and Shai $(2010,42)$ have shown links between HIV/AIDS, violence, poverty. These intersecting theories of violence, poverty, vulnerability to disease and intergenerational trauma provide the theoretical bases for HAICU's engagement with the student population.

\section{THE LINK BETWEEN HIV STIGMA AND INTERGENERATIONAL TRAUMA}

The reason that a unit involved in HIV and Inclusivity work both within and alongside the University curriculum engaged on the topic of the Holocaust is worth explaining. While HAICU has for 22 years engaged with teaching around HIV, it has done so not solely as a health issue, but as an issue around which the staff could teach about power and inclusion.

As co-editor, Crain Soudien (current issue) writes in the introduction to this special issues, 'This special issue is about the social syndromes which a movement such as decolonisation seeks to engage; exclusion, marginalisation, misrecognition, delegitimation, othering, the denial of dignity, conceits of superiority, bystanding, apathy, racism, sexism and all the other forms of power, structural and discursive, that serve to oppress and deny the humanity of some.'

Through researching and teaching around bystander responses to the Holocaust, we were similarly engaged in opening up for discussion among students similar topics that we believe are essential for current graduates in Humanities. Lessons learnt in this endeavour had lessons for teaching around HIV and exclusion and vice versa.

Higher Education Institution staff including academics in South Africa can benefit from understanding the multiple levels of trauma that their students face, and to create spaces to deal with the intersectionality of oppression, i.e., understanding the intersection of social identities and systems of oppression including categories such as race, class, gender ability, sexual orientation, religion, age have operated to create 'systemic injustice' on 'multiple and simultaneous levels' (Crenshaw 1989, 140). This is particularly pertinent in a country such as 
South Africa which has a history of legalised racial discrimination and documented high levels of gender discrimination. The classroom is an ideal space to question these issues.

Initially it was thought that by putting HIV-positive people onto treatment, stigma would disappear. However, in several areas this has not been the case. Campbell, Skovdall, Mandanhire, Mugurungi, Gregdon and Nyamukapa (2011, 1004-1010) investigated the impact of access to ARVs on stigma as experienced by 118 treatment users in Zimbabwe. They reported that while access to ARVs allowed greater social and economic participation, the impact of stigma endures. In the case of Zimbabwe, 'Stigma remains strong, and antiretroviral treatment users remain mired in conflictual symbolic relationships between the AIDS people and the untested. To date, the restoration of users' own sense of self-worth through treatment has not reduced fear and sexual embarrassment in framing responses to people living with HIV/AIDS' (Campbell et al. 2011, 1004-1010). This brings the issue of HIV stigma into an area where people with HIV are judged as being less worthy than those who perceive themselves to be HIV negative.

Kurt, Ephraim and Peters (2012, 1750-1751) define 'inclusion' as being 'about creating empowering environments of difference, where people can be themselves, comfortably contributing their full selves and all the ways in which they differ, and respect others without making it difficult for others to be their full selves' (Kurt et al. 2012, 1750-1751). In 2008, Soudien and the Ministerial Committee on Transformation, Social Cohesion and the Elimination of Discrimination in Public Higher Education Institutions wrote a State of the Nation report for the Department of Education. This report makes the crucial point that discrimination of any kind at HEIs is costly (Soudien 2008, 14).

The costs are psychological as well as physical. The human dignity of both the perpetrator and the victim is abused in the process. Psychologically, discrimination does grievous mental harm to those who believe that they are superior to other human beings. And it obviously has a devastating effect on the victims of such discrimination. Victims are denied the opportunity either through a lack of access to opportunities or due to outright discrimination to realise their full potential. In the process the country is robbed of valuable but untapped human resources. Higher education institutions cause incalculable damage to South African society by failing to deal boldly with these issues.

Whether University staff is teaching about racial or religious oppression or about HIV discrimination, there is a way to speak about how to attempt to enable inclusion in the way in which material is taught as well as what is taught.

Hoffman $(2001,72)$ says that after mass political trauma, what is transferred is 'loss rather 
than transferred memory,' and suggests that 'the role for second and third generation survivors [of political trauma] is far from easy. The legacy passed on was not a processed, mastered past, but the splintered signs of acute suffering, of grief, of loss' $(2001,52)$. Hoffman also refers to personal and psychoanalytic literature that reports recurrent patterns in some people with signs of intergenerational trauma, such as 'Difficulties in forming relationships; a pervasive sense of guilt; a need to achieve and over-achieve (to compensate for parental loss); insistence on perfectionism and intense fear of punishment' (Hoffman 2001, 56).

Volks (2012, 41-42) interviewed three Higher Education students living with HIV. The students spoke of a number of intersecting concerns around their HIV status, their parent's expectations for them to achieve their own self-esteem and their perceptions of their performance at UCT. It is as if their parents, who had not been given an opportunity to achieve during apartheid, had deposited all their hope in their children and yet, instead of encouragement, this was translated into a burden for the students.

In the case of a second year student (Sivu) who name has been changed, finding out that she was HIV positive led to the family realising Sivu's mother was HIV positive and that she transmitted HIV to her daughter in utero. At the time Sivu was told of her HIV status, she was told that she could not see her mother and the mother was 'banished' from their house. Sivu was told by her grandparents never to tell anyone about her HIV status and that they would not discuss it with her. She talked of trying to speak to her cousin, who told her not to discuss it with her. This clearly sent a message to Sivu regarding how she herself should think about HIV. She spoke in 2012 of people in her township saying that if they got HIV they would commit suicide. Sivu also spoke of a friend she met in class at UCT who told her, 'If you got HIV, I'd laugh at you'. Sivu spoke of feeling silenced by this. When Sivu did not do well at her academic studies, she spoke of being told to work harder by her grandparents and her supervisor, but it is clear that she worked as hard as she could, but was battling multiple traumas.

Thabelo carries the academic pressure to achieve, but felt unable to disclose his status to his parents. 'I do feel guilty sometimes because of what was expected. As much as their expectations, I'm not sure they understand it's not easy to deliver some of their expectation. I can't tell my mom (about the HIV). They expected only good things. They didn't process that (what) you go through to achieve.' Thabelo also speaks of daily financial struggles. He says, 'I was very unprepared for the cold [of the Cape Town winter] because I'm used to Durban weather. It's freezing and people would be like, “Why are you wearing shorts?” It's not like you want to be wearing shorts.' (Volks 2012, 41-42).

A fifth year student, whose name was changed to Aaron and who identifies as gay, said 
his mother was unemployed when he was at secondary school, but she occasionally worked as a domestic worker. Her life was clearly affected by apartheid. He says, 'My mom, I haven’t told her (about the HIV). I'm trying to protect her because I have been stalling and stalling to tell her. I told my sister and asked her; please don’t tell mum, you know how fragile she is and all that'. He also speaks of his family and school having big expectations of him achieving at University.

These students' words indicate an intersection between HIV and possible intergenerational trauma as well as between categories of class, race, sexuality, gender and other constructs.

\section{METHOD}

We set out to investigate the outcome on Cape Town Holocaust Centre facilitators of witnessing a video of a representative of bystanders of German Nazi persecution apologising to a descendant of victims of Nazi persecution. We proposed showing the video of Father Norbert Littig, a representative of a bystander in a small German town where there was only one Jewish family (the Schonwalds), some of whom fled and some of whom were killed by Nazis, speaking about and acknowledging what happened in Nazi Germany to the Schonwalds, to an audience of holocaust facilitators from The Cape Town Holocaust Centre who are trained at the holocaust centre to lead education tours. The assessment sought to determine the outcome on the facilitators in understanding of the role of the bystander with the purpose of adapting this for history students. Participants were asked to fill in an evaluation tool following the presentation. The Vision and Mission of the organisation is as follows:

The South African Holocaust and Genocide Foundation strives to further Holocaust education through: providing accurate historical content knowledge of the Holocaust to develop an understanding of the past ; facilitating the making of connections between the Human Rights atrocities committed during the Holocaust so that the moral and ethical issues raised can be instructive in dealing with contemporary challenges of human rights abuses, for example xenophobia, racism and bigotry; encouraging a commitment to the protection of Human Rights to support the building of a Human Rights culture and to encourage respect for diversity; encouraging social activism and a greater individual responsibility to building the community; and encouraging empathy and compassion and a deeper understanding of what it means to be human. Volunteer educators work mostly with high school learners in Grades 9-12 but also with tertiary students and adult groups. Sessions usually run for four hours with most (but not all) groups in the morning. The volunteers' responsibilities include facilitating a tour through 
the exhibition, and assisting with discussions and other group activities in the workshop. Training is provided for the volunteer educators. Volunteers have the 'wonderful opportunity of working with young and old, examining issues of Human Rights' (Cape Town Holocaust Centre 2014, 1).

\section{Method of data analysis}

Data was collected and coded using grounded theory (Glaser and Holton 2004, 2). The effect of witnessing the videos and reflecting was analysed for both groups, with similarities and differences drawn out. The data is disguised to protect the identities of participants.

\section{Research permission}

Ethical permission to conduct the research was obtained through the UCT Organisational Psychology Department and the Commerce Faculty Ethics Committee. Participants completed a consent form.

\section{LIMITATIONS}

We are not making claims about the video changing attitudes in the participants since any views expressed may or may not be affected by the video. We wanted to understand the video as a tool for eliciting discussion around different viewpoints around bystanders then and now and their descendants and the outcome of apologies on descendants of victims. We also spent just under two hours with the group. The outcome may have been more effective with follow-up.

\section{CASE STUDY}

Suze (born 1915) Schonwald Lachmann's family (her parents Curt and Regina Schonwald and her brother Heinz) lived as the only Jews in the small town of Grossrohrsdorf near Dresden, Germany. The family owned a textile shop, Kaufhaus Schonwald. On the night of the 9th November 1938, what was subsequently called Kristallnacht, a group of Nazi supporters smashed the shop windows and looted the Schonwald's store. Curt and Regina were then marched through the streets to the local police station. Curt was arrested and sent to Buchenwald concentration camp, before being released to sell his shop. Suze and her husband Alfred emigrated from Germany in 1939, travelling via Amsterdam, London and Cape Town, before settling in Rhodesia. Suze's brother Heinz immigrated to America in 1939. But Curt and Regina were unable to get emigration Visas. A Gestapo memorandum dated 28th March 1942 reports that Curt and Regina Schonwald (no’s. 10326 and 10327, respectively) were transported by 
train to Trawniki labour camp near Lublin in Poland. The Gedenkbuch, a post-war archive compiled to document the fate of German Jews under National Socialism, confirms the transport but is silent about what happened next to Curt and Regina. The Encyclopedia of the Holocaust notes that many Trawniki inmates died of starvation and disease while others were sent to the Balzac death camp for extermination. Possibly, they were among the ten thousand Jewish inmates of Trawniki shot on November 5, 1943 following an uprising in the Sobibor Camp.

When East Germany collapsed in 1989, Germans were able to write about what had been forbidden during the communist era. Three men wrote up the Schonwald family story. Norbert Littig, a Lutehran Minister who had counselled Nazi bystanders and their offspring who lived in the town of Grossrohrsdorf; Eckhardt Hennig, a retired history teacher, worked with Norbert in part because of his childhood memories of Kristallnacht (his father who had been hired by Curt Schonwald to replace the shop windows following Kristallnacht, was subsequently ostracized by the Nazi government). Mattias Meth, the architect commissioned to restore the Schonwald's store, became interested in the history of the building and its occupants.

As part of an Erasmus Mundus scholarship addressing HIV stigma, Ms Volks visited the Institute of Ethnology Programme at the Freie University of Berlin in 2012. During this visit, she had an opportunity to visit the Schonwald store in Grossrohrsdorf and meet Father Norbert Littig. Ms Volks was able to obtain video footage of Father Littig, discussing his journey researching the Schonwald history and the process of reconciliation for the town, culminating in the erection of a memorial to the Schonwalds on the 70th anniversary of Krsitallnacht in 2008. The inscription on the memorial states that it is as much for the residents of Grossrohrsdorf to commemorate their painful past as it is for the Schonwald descendants.

Quoting from Norbert's book about Kristallnacht (and these quotes were translated from the German by Steffi Hawkes and read to the participants in the outcome study):

Around 2.30 am a relatively small group of 'overzealous party members' gathered in front of the Schönwald's department store in Grossröhrsdorf shouting out 'Jude raus!' Curt and Regina ... were dragged out violently and had to watch stones flying into ... the store's window panes. Swastikas were smeared on other store windows and the word 'JUDE' was written in capital letters on ... the house.

The Schonwalds were taken to the police station, later released then fled to Berlin and later sent to a concentration camp. A contemporary witness, who observed the incident, reported that the group was not a ‘crowd' but rather a relatively small group (Erbaut 1928). Hans Gebler a witness who wrote a document on the night of Kristallnacht (in a blue file) indicates the majority 
of people in the town did not want this to happen, that it was a small group of outsiders who drove the Schonwalds out of the town.

Norbert, Eckhart and the residents paid for a memorial to the Schonwalds which was erected in 1998. There is a picture of the Schonwalds with shattered glass covered by shatterproof glass to remember Kristallnacht. The inscription translated by Norbert Littig reads as follows:

Here lived Curt and Regina Schonwald with their children, Heinz and Suze. Since 1928 they had a well-known textile shop. On the night 10/11/38 this shop was damaged by a little group of National Socialists. They destroyed the windows. Curt and Regina had to move through the city. The oldest inhabitants say, 'It was terrible and we are ashamed that we didn't do anything against this terrible thing'. Heinz and Suze emigrated, but the parents were deported from Berlin in 1942. In this time we can't change what happened, but now we have to remember every day. This is our part, for us and for our children. We will remember with this family.

\section{RESULTS}

There were 11 participants who watched the apology. Of the eleven, ten facilitators completed the questionnaires. Participants age ranged from 20-60 years and the group comprised of both male and female facilitators.

When asked what key messages they took away from the video, one responded said, 'Use the past to teach'; another responded indicated that 'the people in the town did not want to be part of the Kristallnacht demonstration and most people felt they could do nothing to stop the group'. One respondent noted that 'It was a small group who participated, but we should all remember'.

Facilitators were asked to comment on the meaning of the acknowledgment of the bystanders' role in the Sconwalds' deaths for participants involved. The first response was that 'It allows people to work through past feelings of guilt'. Another respondent said that the video is 'an acknowledgement of human weakness in supporting and enabling Nazi prejudice and discrimination'. Further, the apology was said to be 'a memorialisation to make awareness for generations to come'. Another key was taken away was that 'It takes courage to do this'. The final response was that 'people are distancing themselves from what was done, they feel guilty and responsible’.

With regards to the question of how the Memorial inscription increased understanding of the variety of people affected in Grosrohrsdorf, six views were presented. Four views were positive, one was neutral and another was negative. These views are presented below:

Respondents to the above question said that 'everyone is affected by evil deed and that the responsibility to remember a tragedy should be remembered by its present and future 
generations'.

One respondent specifically stated that the apology is 'a permanent record of their views and work'.

The negative view presented was that 'It did not increase my understanding' (This may be because the person already had an understanding prior to watching the video or it may be because the video failed to affect the person).

Another negative view was that there was 'no new knowledge or understanding gained because there is too much emphasis on perpetrators, detracting from victims'.

In the focus group following the individual questionnaires, three themes emerged. The first theme is perceptions about agency. Were bystanders really unable to intercede on the part of the victims or not and did this affect the way they are viewed in contemporary times? The second theme was perceptions around credibility. The key question in this theme is whether Norbert is a credible representative of the bystanders? The last theme that emerged was perspectives on forgiveness. Do some bystanders and their descendants need to be told they are 'forgiven' to release guilt and grief? Is it appropriate for descendants of bystanders (who were not directly involved) to apologise to descendants of victims (who were not directly involved) and for descendants of victims to acknowledge the apology?

\section{Agency}

Abrahams (1982, 3-14) points out that 'the problem of agency is the problem of finding a way of accounting for human experience which recognises simultaneously and in equal measure that history and society are made by constant and more purposeful individual action and that individual action, however purposeful, is made by history and society’ (Abrahams 1982, 3-14).

Of the ten respondents, two claimed that it was a small group that rampaged outside the Schonwald store on Kristallnacht who demonstrated more complicity in bystanders not doing something. Respondent 1 felt the memorial was 'too apologist' and presented to bystanders in a kinder light than perhaps she thought should have been said. This respondent said, 'I'm concerned that if you were to show this to people as a way of perhaps showing the nuance of human behaviour, this piece which suggests that this is a small group of people that were responsible, if the group was so small you would have thought that there could have been something that could be done'.

According to members of the focus group, the 'evidence' of historical facts that proved the bystanders on the night were against what happened was critical. Respondent 3 said, 'That document that was written that night is very important. There were some people that supported 
this family.' Similarly, respondent 5 said, 'The fact that there were eye witness accounts on the night means that people were trying to talk about it at the time'. This aspect of this case study, that miraculously Hans Gebler wrote notes on the night, that the document survived and that Norbert and his colleagues wrote a book about it, enables an understanding of contextual complexity with the bystanders and even empathy. Respondent 3 went on to demonstrate this when she said, 'If something like this happened, it's all very well in hindsight to say how many people stood up but if you are threatened, you don't know what you are going to do. You can't really judge these people. I know for me with my children I don't know if I would have gone and stood in the way.' However, what is the case in specific situations where there is no 'evidence' that bystanders were against what was happening; are those bystanders to be denied our collective empathy?

Even with concerns about Norbert, respondents 1 and 2 were at least willing to listen and reflect on credibility. Respondent 1 who originally expressed concern that Norbert's actions might be too apologist, mentioned at the end of the session that when the Holocaust Centre has functions with invited German embassy representatives she always feels bad for the Germans when the history is referred to and wants to protect them. This demonstrated another layer from the comments earlier and a level of empathy with descendants of bystanders and perpetrators.

\section{Credibility}

Of the eleven facilitators, two noted that the fact that Norbert was not actually there during Kristallnacht made him less able to represent other bystanders. This seemed, for them, to detract somewhat from the apology. Respondent 1 said, 'I don't think that you can put Norbert and the people he's representing in the same category. Norbert is a religious leader. He's an outsider in the community. He has a position in the community. He's able to interrogate what happened.' Respondent 1 does not feel that Norbert accurately represents the views of many bystanders. In this vein, Respondent 2 said, 'I really felt the sense of guilt from Norbert yet the voice of the others is not heard. What impact will that make if there's no-one else saying ... there should be reconciliation? The fact that they paid for it [the memorial stone] does that really create the debate that is needed for memorialisation?' For Respondent 2 what the representatives and descendants of bystanders have tried to do is not enough. However, Respondent 5 then argues why she feels Norbert is credible and does represent some of the bystanders' views. She said, 'What I'm struck by is here is one person who feels not only must he find out, but he's got a very clear message that he wants people to remember. People put money into commemorating something to which the present generation could very easily have said, 'Look, we're very sorry 
for what our grandparents did or didn't do, but what does that have to do with us? And of course it's flawed. But what would the right thing be? The right thing would be that it never happened, but it did.'

\section{Empathic repair}

Gobodo-Madikizela $(2015,11)$ notes that most scholars discussing forgiveness form a psychoanalytic perspective to recognise the crucial relationship between remorse and forgiveness. Gobodo-Madikizela (2008, 332) notes the need for perpetrators and bystanders to be forgiven in a post conflict transitional society and the difficulty this poses for victims; how should the pathos of perpetrators and bystanders be handled? How do you forgive ... unless you find the claims of remorse credible? And how do you find them credible unless you first understand why they did it? Respondent 6 also elaborated on the descendants' need to be forgiven. She said [referring to another apology of contemporary Germans to a surviving German Jew whose family was invited back to Germany], 'The current mayor of the German town said we would never ask you to forgive us, but the fact that you came back with your family means so much to us .... [The returning Jew] said, "Of course I forgive you. I forgave you a long time ago, but I will never forget ...”. They need people to say to them it's ok. And only then do they feel it's right for them to move on ... If it helps them, it helps us as well.'

More recently in South Africa in 2015 there has been much public discussion about whether the Rainbow Nation was constructed post 1994 with too much emphasis on forgiveness and insufficient emphasis on reparations and justice and this is a crucial topic of discussion for Humanities curricula. In this case study reparations were paid for a lost business. More research needs to be done around whether people in South Africa have paid insufficient attention to monetary reparations, whether apologies have been positioned 'in place of' reparations.

\section{RECOMMENDATIONS}

Our response to the feedback from the Holocaust volunteers was to foreground the role of other bystanders more in the presentation. In Norbert's Book, he refers to Norbert's description of Suze's nephew, History and Jewish Studies Prof Kenneth Wald: 'On his return visit to Großröhrsdorf in 2004, Kenneth Wald said the highlight of the visit ... was the encounter between the last living sales-lady Elfriede Graf and six former customers of Schönwald's department store. ... They spoke about early memories of times from their youth'. In an interview with the Gainsville Sun (Gainsville is where Kenneth is based it is stated, 'Ken’s views toward Germany have changed from that of bigotry and wanting revenge to now wanting to see reconciliation. Following addressing the town residents in 2008, Ken Wald said he was 
unprepared for the outpouring of tears [from descendants of bystanders] following his comments [around forgiveness]' (The Gainesville Sun 2009). We also elected to foreground in the presentation why Norbert's account of these bystanders may be credible. In the blue file Johannes Gebler (1900-1959) made the following entry: '10 November 1938: 2h30 - 4h30 all shop windows were smashed under supervision of the party. Under duress from overzealous party comrades this event had to be heralded through church bells. The general public do not understand why this is happening.'

The researchers recommend that this kind of material be used in academic curricula across a range of subjects in the Humanities. It is important to update the debate to the contemporary debates around apologies, land, reparations and truly addressing structural inequity in South Africa.

\section{CONCLUSION}

In conclusion, we found that discussing the implications and apologising for the violence that happened from the perspective of a bystander, their descendants or their representative and showing the apologies to broader audiences in spaces where people can discuss the extent of complicity and complexity of perpetrators and bystanders is a valuable strategy for teaching several aspects of life following political trauma. These are conversations that are overdue. Apologies must be discussed alongside reparations and bringing perpetrators to justice.

\section{REFERENCES}

Abrahams, P. 1982. Historical Sociology. Ithaca University Press.

Campbell, C., M. Skovdall, C. Mandanhire, C. Mugurungi, S. Gregdon and C. Nyamukapa. 2011. We, the AIDS people ...: How antiretroviral therapy enables Zimbabweans living with HIV/AIDS to cope with stigma. American Journal of Public Health 101(6): 1004-1010.

Chigumadze, P. 2016. We don't want white apologies, we want our land back. Rand Daily Mail, 13 January 2016.

Crenshaw, K. 1989. Demarginalizing the intersection of race and sex: A Black feminist critique of antidiscrimination doctrine, feminist theory and antiracist politics. The University of Chicago Legal Forum 140: 139-167.

Erbaut, N. 1928. Erinnerung an die jüdische Familie Schönwald aus Grossröhrsdorf. Wilkau-Hasslau: Zschiesche, 2008.

Gobodo-Madikizela, P. 2008. Empathic repair after mass trauma: When vengeance is arrested. European Journal of Social Theory 11: 331.

Gobodo-Madikizela, P. 2015. Psychological repair: The intersubjective dialogue of remorse and forgiveness in the aftermath of gross human rights violation. Journal of American Psychological Association 63: 1085-1125.

Glaser. B. and J. Holton. 2004. Remodelling grounded theory analysis. Qualitative Social Research 5(2): 774.

Jewkes, R., K. Dunkle, M. Nduna and N. Shai. 2010. Intimate partner violence, relationship power 
inequality and incidence of HIV infection in young women in SA: A cohort study. The Lancet 376, 1-8.

Hoffman, M. L. 2001. Empathy and moral development: Implications for caring and justice. Cambridge University Press.

Kurt, A., N. Ephraim and K. Peters. 2012. Diversity management in South Africa: Inclusion, identity, intention, power and expectations. African Journal of Business Management 6(4): 1749.

Msimang, S. 2014. Oops, I'm a racist! When perpetrators become victims. Daily Maverick, 25 September 2014. http://www.dailymaverick.co.za/opinionista/2014-09-26-oops-im-a-racistwhen-perpetrators-become-victims/\#.Vuh0-J0aLIU (accessed 15 March 2016).

Soudien, C. 2008. Report of the Ministerial Committee on Transformation and Social Cohesion and the elimination of discrimination in public Higher Education institutions. The National Department of Education of South Africa.

The Cape Town Holocaust Centre. 2014. Cape Town Holocaust Centre. http://www.ctholocaust.co.za/ pages/overview.htm (accessed 15 November 2012).

The Gainesville Sun. 2009. University of Georgia professor sought after wife, two others fatally shot. April 26. http://www.gainesville.com/article/20090426/ARTICLES/904269986\# (accessed 11 April 2016).

Volks, C. 2012. Are they really born free? Assessing and addressing experiences of stigma and the intersection of discrimination around race, language, class, gender and sexual orientation, of UCT HIV positive students in 2006-2012. http://www.haicu.uct.ac.za/hiv/about/overview (accessed 8 April 2016). 